\title{
Determination of Metformin in Human Plasma and Urine by High- Performance Liquid Chromatography Using Small Sample Volume and Conventional Octadecyl Silane Column
}

\author{
Raniah Q. Gabr ${ }^{1}$, Raj S. Padwal ${ }^{1,2}$ and Dion R. Brocks ${ }^{1,2}$ \\ ${ }^{1}$ Faculty of Pharmacy and Pharmaceutical Sciences, University of Alberta, Canada. \\ ${ }^{2}$ Department of Medicine, Faculty of Medicine and Dentistry, University of Alberta, Canada.
}

Received, October 22, 2010; Accepted, November 5, 2010; November 9, 2010.

\begin{abstract}
Purpose. To develop a selective and sensitive high-performance liquid chromatographic method for the determination of metformin in human plasma and urine, using a conventional reverse phase column and low specimen volume. Methods. Extraction of metformin and ranitidine (as internal standard) from plasma and urine samples $(100 \mu \mathrm{L})$ was performed with a 1-butanol-hexane $(50: 50, \mathrm{v} / \mathrm{v})$ mixture under alkaline conditions followed by back-extraction into diluted acetic acid. Chromatography was carried out using a C18 column $(250 \mathrm{~mm} \times 4.6 \mathrm{~mm}, 5 \mu \mathrm{m})$. A mobile phase consisting of acetonitrile and $\mathrm{KH}_{2} \mathrm{PO}_{4}(34: 66, \mathrm{v} / \mathrm{v})$ and sodium dodecyl sulphate $(3 \mathrm{mM})$ was pumped at an isocratic flow rate of $0.7 \mathrm{~mL} / \mathrm{min}$. Results. The calibration curves were linear $(>0.995)$ in the concentration ranges of $10-5000$ $\mathrm{ng} / \mathrm{mL}$ and $2-2000 \mu \mathrm{g} / \mathrm{mL}$ for metformin $\mathrm{HCl}$ equivalents in plasma and urine respectively. The mean absolute recoveries for 100 and $1000 \mathrm{ng} / \mathrm{mL}$ metformin $\mathrm{HCl}$ in plasma using the present extraction procedure were 93.7 and $88.5 \%$, respectively. The intra- and inter-day coefficients of variation in plasma and urine were $<20 \%$ at the lowest, and $<16 \%$ at other concentrations. The percent error values were less than $2 \%$ in plasma while it reached $\sim 9 \%$ in urine. The lower limits of quantification were $7.8 \mathrm{ng} / \mathrm{mL}$ and $1.6 \mu \mathrm{g} / \mathrm{mL}$ of metformin base in plasma and urine respectively. Conclusions. The method showed high calibers of sensitivity and selectivity for monitoring therapeutic concentrations of metformin in both plasma and urine based on a $0.1 \mathrm{ml}$ sample size.
\end{abstract}

\section{INTRODUCTION}

Metformin $\mathrm{HCl}$ (1,1-dimethylbiguanide $\mathrm{HCl}$ ), first developed in 1957, is one of the most commonly used oral anti-hyperglycemic agents for the treatment of Type II diabetes mellitus. In 1995, the FDA approved metformin $\mathrm{HCl}$ for use in the United States, which led to a significant increase in clinical use (19). It is currently recommended as first-line therapy in overweight or obese patients with this condition (1).

Many methods are available for quantitation of metformin in biological samples. For its separation from endogenous components most of these methods rely on liquid or gas chromatographic steps (Table 1) (2-9,11-15,1718,22-27). Others involving capillary electrophoresis have also been reported (21). Regarding sample preparation from biological fluids, extraction and clean-up of the sample is a critical first step in bioanalysis and requires high selectively for the removal of interfering substances, while ensuring minimal analyte loss. The extraction of metformin from biological matrices is somewhat complicated by the highly polar nature of the molecule. This factor, in addition to the drugs widespread clinical use, may explain the relative abundance of different methods for analyzing metformin in biological specimens. Many of the current methods utilize varying techniques for sample cleanup, such as simple protein precipitation, solid phase extraction, ultrafiltration with column switching, chemical derivatization and liquid-liquid extraction.

Correspondence Author: Dion R. Brocks, Ph.D. Professor and Associate Dean, Faculty of Pharmacy and Pharmaceutical Sciences, 3118 Dentistry/Pharmacy Centre, University of Alberta, Edmonton, AB, Canada, E-mail: dbrocks@pharmacy.ualberta.ca 
Table 1. Comparisons of some published methods for assaying metformin in human matrices

\begin{tabular}{|c|c|c|c|c|c|}
\hline $\begin{array}{l}\text { Volume of } \\
\text { specimen } \\
(\mathrm{mL})\end{array}$ & $\begin{array}{c}\text { Validated } \\
\text { plasma LLQ } \\
(\mathrm{ng} / \mathrm{mL})\end{array}$ & $\begin{array}{l}\text { Type of } \\
\text { human } \\
\text { matrix }\end{array}$ & Sample preparation & $\begin{array}{l}\text { Analytical } \\
\text { column }\end{array}$ & Reference \\
\hline 0.5 & 30 & Plasma & $\begin{array}{l}\text { Protein ppt and dichloromethane } \\
\text { wash }\end{array}$ & Phenyl & (17) \\
\hline 0.1 and 0.5 & 10 & Plasma & $\begin{array}{c}\text { Protein ppt and dichloromethane } \\
\text { wash }\end{array}$ & Silica & (7) \\
\hline $\begin{array}{l}1 \text { serum } \\
\text { NS urine }\end{array}$ & $\begin{array}{l}50 \text { serum } \\
2000 \text { urine }\end{array}$ & $\begin{array}{l}\text { Serum \& } \\
\text { urine }\end{array}$ & Ion pair SPE & $\mathrm{C} 18$ or F5HS & (23) \\
\hline 0.1 & 15.6 & Plasma & Liquid-liquid & Silica & (3) \\
\hline 0.5 & 200 & $\begin{array}{c}\text { Plasma \& } \\
\text { urine }\end{array}$ & Protein ppt & $\mathrm{CX}$ & (5) \\
\hline NS & 10 & NS & Protein ppt & Silica & (18) \\
\hline 0.3 & 100 & Plasma & Ultrafiltration & CX & (24) \\
\hline 0.25 & 60 & Plasma & Protein ppt & Cyano & (12) \\
\hline 0.1 & 250 & Plasma & IPE & Silica & (21) \\
\hline 0.5 & 50 & Plasma & SPE C8 & Phenyl & (11) \\
\hline 1 & 10 & $\begin{array}{c}\text { Plasma \& } \\
\text { urine }\end{array}$ & IPE & $\mathrm{C} 18$ & (13) \\
\hline 0.1 & $7.8^{*}$ & $\begin{array}{c}\text { Plasma \& } \\
\text { urine }\end{array}$ & Liquid-liquid & $\mathrm{C} 18$ & Current method \\
\hline
\end{tabular}

Abbreviations: $\mathrm{LLQ}=$ lower limit of quantitation, $\mathrm{SPE}=$ solid phase extraction, protein $\mathrm{ppt}=$ protein precipitation, $\mathrm{IPE}=$ ion pair extraction, $\mathrm{LLE}=$ liquid-liquid extraction, $\mathrm{F} 5 \mathrm{HS}=$ pentaflorohypersil, $\mathrm{CX}=$ cation exchange. NS denotes not specified or unclear. *Equivalent to $10 \mathrm{ng} / \mathrm{mL}$ of the $\mathrm{HCl}$ salt.

Ion-pair liquid-liquid $(13,21)$ or ion-pair solidphase extraction (23) has been used to overcome clean up plasma samples, which is difficult to achieve owing to the high polarity of metformin. Use of other solid-phase extraction (11) and ultrafiltration with column switching (24) steps have also been incorporated into some methods, although they are not always yield optimal sensitivity, and may necessitate the use of certain devices which can add elements of expense and time into sample preparation. Chemical derivatization of metformin has been used in gas chromatography $(4,15)$ and HPLC methods (22), but these can add complexity into the method with little advantage in terms of sensitivity. Recently, liquid chromatographymass spectrometry (LC-MS) methods following plasma deproteination have been reported for metformin $(6,9,25)$ and these techniques certainly enhance selectivity and sensitivity. They have a disadvantage however in that the instrumentation is quite expensive is not as accessible as conventional HPLC in most laboratories, particularly in clinical laboratories.

Organic liquid-liquid extraction is a simple and effective method of affording sample cleanup for most analytes. Unfortunately, in the case of metformin, this approach is challenging because of the drug's polar characteristics. Herein, a method that successfully employs the liquid-liquid extraction of metformin and capable of measuring metformin in small volumes with high sensitivity is described. The extraction method was similar to that described by another group (3), although here a conventional reverse phase $\mathrm{C} 18$ column could be used for separation.

\section{METHODS}

\section{Materials and reagents}

Metformin $\mathrm{HCl}$ (purity of 97\%) was purchased from Sigma-Aldrich (St. Louis, MO, USA). Ranitidine injection USP (Sandoz, Quebec, Canada) was used as a source of ranitidine $\mathrm{HCl}$ 
for internal standard (IS) and purchased from the University of Alberta Hospitals (Edmonton, Alberta, Canada). Acetonotrile, hexane and water (all HPLC-grade) were purchased from Caledon Laboratories Ltd (Georgetown, Ontario, Canada). Sodium dodecyl sulphate (SDS) was purchased from Anachemia (Mississauga, Ontario, Canada). Analytical grade 1-butanol and $\mathrm{KH}_{2} \mathrm{PO}_{4}$ were purchased from Caledon Laboratories Ltd (Georgetown, Ontario, Canada).

\section{Instrumentation and chromatographic conditions}

The chromatographic system consisted of a Waters (Milford, MA, USA) 600E multi-solvent delivery system pump, auto sampler with variable injection valve (Waters 717) and UVvisible tunable absorbance detector (Waters 486). The chromatograms were recorded using EZStart software (Scientific Software, Pleasanton, CA, USA) in a computer system for data collection and processing. Separation was performed on a $250 \mathrm{~mm} \times 4.6 \mathrm{~mm}$ i.d., $5 \mu \mathrm{m}$ particle size Alltima C18-column (Alltech, Deerfield Il, USA). The mobile phase consisted of acetonitrile-potassium dihydrogen phosphate buffer $\mathrm{pH} 6.5(34: 66, \mathrm{v} / \mathrm{v})$ and $3 \mathrm{mM}$ SDS. It was prepared daily and degassed by filtering it under vacuum through a $0.045 \mu \mathrm{m}$ nylon filter. The flow rate of the mobile phase through the analytical column was $0.7 \mathrm{ml} / \mathrm{min}$, at room temperature. The detection wavelength was set at $236 \mathrm{~nm}$.

\section{Standard and stock solutions}

A stock solution of $5 \mathrm{mg} / \mathrm{mL}$ metformin was prepared by dissolving $100 \mathrm{mg}$ in $20 \mathrm{~mL}$ of water. Working solutions were prepared freshly on the day of experiment from the stock by successive dilutions with water. Calibration samples of plasma $(0.1 \mathrm{~mL})$ were prepared containing metformin $\mathrm{HCl}$ equivalent to 10,30 , $100,500,1000,2000$ and $5000 \mathrm{ng} / \mathrm{mL}$. For urine, $0.1 \mathrm{~mL}$ samples containing metformin $\mathrm{HCl}$ equivalent to $2,20,100,500,1000$, and $2000 \mu \mathrm{g} / \mathrm{mL}$ were prepared. These samples were used for generation of standard curves.

An IS stock solution of $25 \mathrm{mg} / \mathrm{mL}$ of metformin $\mathrm{HCl}$ was further diluted in water to prepare the working solution of 25 and 250 $\mu \mathrm{g} / \mathrm{mL}$ for plasma and urine analysis respectively. All stock solutions were kept at $5^{\circ} \mathrm{C}$ until use.

\section{Extraction procedure}

The extraction procedure was similar to that described by Amini et al. (2005), with some modification. To $100 \mu \mathrm{L}$ matrix was added 20 $\mu \mathrm{L}$ of IS $(25 \mu \mathrm{g} / \mathrm{mL})$ solution in case of plasma, or $30 \mu \mathrm{L}$ of IS $(250 \mu \mathrm{g} / \mathrm{mL})$ in case of urine. An $80 \mu \mathrm{L}$ volume of $10 \mathrm{M} \mathrm{NaOH}$ was added to alkalinize the media. Analytes were then extracted using a $3 \mathrm{~mL}$ mixture of 1-butanol: hexane $(50: 50 \mathrm{v} / \mathrm{v})$. The tubes were vortexmixed for $30 \mathrm{~s}$ and centrifuged at $3000 \mathrm{~g}$ for 3 min. The supernatant (organic layer) was transferred into clean glass tubes and acidified with $500 \mu \mathrm{L}$ of $0.2 \%$ acetic acid, vortex-mixed for $60 \mathrm{~s}$ and centrifuged at $3000 \mathrm{~g}$ for $3 \mathrm{~min}$. The supernatant was removed by aspiration using a pipette attached to a vacuum flask, and the remaining aqueous layer was evaporated to dryness in vacuo. The residues were reconstituted with $200 \mu \mathrm{L}$ HPLC water. The injection volume into the chromatographic system ranged from $60-70 \mu \mathrm{L}$.

\section{Recovery}

The recoveries were determined with metformin $\mathrm{HCl}$ concentrations of 100 and $400 \mathrm{ng} / \mathrm{mL}$ of plasma, and $100,2000 \mu \mathrm{g} / \mathrm{mL}$ of urine using four replicates for each concentration. The extraction efficiency was determined by comparing the extracted peak heights of analyte in samples to the peak heights of the same amounts of analyte directly injected to the instrument, without extraction.

\section{Calibration, accuracy and validation}

Full inter and intraday validation assessment was undertaken in human heparinised plasma samples. After validation was established in plasma, for urine a partial (one day) validation was undertaken. Samples were processed by adding IS and known amounts of metformin $\mathrm{HCl}$ to $100 \mu \mathrm{L}$ human matrix providing a metformin $\mathrm{HCl}$ concentration range of $10-5000 \mathrm{ng} / \mathrm{mL}$ in case of plasma and $2-2000 \mu \mathrm{g} / \mathrm{mL}$ in case of urine. The ratios of metformin base to IS peak height were calculated and plotted vs nominal metformin concentrations to construct 
calibration curves. Data for calibration curves were weighted by a factor of 1 /concentration due to the wide range of concentration used.

Intraday, accuracy and precision of the assay were determined using a range of concentrations of metformin $\mathrm{HCl}$ in both matrices. The concentrations were selected at 10,30, 100, 500 and $1000 \mathrm{ng} / \mathrm{mL}$ and at 2, 20, 100, 500 and 2000 $\mu \mathrm{g} / \mathrm{mL}$ for human plasma and urine respectively. The urinary concentrations were selected to be higher because the drug is excreted extensively in urine, and concentrations were expected to be high as a result (16). Each concentration had a replicate of five samples. Regarding human plasma samples, to permit the assessment of interday accuracy and precision, the assay was repeated on three separate days. For each daily run, a set of calibration samples separate from the validation samples were prepared to permit quantification of the peak height ratios of metformin to IS. Precision was assessed by percentage coefficient of variation $(\mathrm{CV} \%)$ while accuracy was represented by determining mean intra- or inter-day percentage error.

\section{Application}

The method was used to determine metformin concentration in plasma and urine samples from two volunteers, after oral administration of 1000 $\mathrm{mg}$ as 2 tablets containing $500 \mathrm{mg}$ of metformin per tablet. Tablets were administered with a glass of water following an overnight fast. Subjects provided written consent, and the study was approved by the University of Alberta Health Research Ethics Board. After dosing, serial blood samples were taken for up to $24 \mathrm{~h}$. The samples were centrifuged for $10 \mathrm{~min}$ after sampling and plasma separated and frozen at $20^{\circ} \mathrm{C}$ until assayed. The terminal phase half-lives were determined by applying regression analysis to the $\log$ linear terminal portion of the concentration vs. time curve. The linear trapezoidal rule was used to calculate the area under the plasma concentration vs. time curve from the time of dosing to the last measured concentration. The maximal concentration (Cmax) and the time to achieve it (tmax) were determined by visual examination of the data.

\section{RESULTS}

The chromatographic retention times were 9.5 min for metformin and $13.5 \mathrm{~min}$ for IS. The method provided specificity, with baseline resolution of IS and metformin with a lack of interfering peaks from endogenous components in plasma or urine (Fig. 1). The peaks were symmetrical. The average recoveries were 93.7 and $88.5 \%$ with 100 and $1000 \mathrm{ng} / \mathrm{mL}$ metformin $\mathrm{HCl}$ in plasma, respectively. In urine, recovery was $83.0 \%$ and 89.4 for 100 and $2000 \mu \mathrm{g} / \mathrm{mL}$, respectively. The average extraction recoveries for IS were 83.3 and $82.7 \%$ in plasma and urine respectively. There were excellent linear relationships $\left(r^{2}>0.995\right)$ noted between the peak height ratios and concentrations over metformin $\mathrm{HCl}$ ranges of $10-5000 \mathrm{ng} / \mathrm{mL}$ plasma, and 2$2000 \mu \mathrm{g} / \mathrm{mL}$ of urine.

Based on regression analysis of the concentration vs. peak height ratios of metformin to IS, in plasma and urine average slopes of 0.00041 and 0.0274 were observed, respectively. Corresponding intercepts were 0.00594 and 0.6385 respectively. The mean $r^{2}$ for plasma and urine standard curves were 0.999 and 0.9972 respectively. The CV of intra-and inter-day assessments for both matrices were less than 19\% (Table 2 and 3). Mean inter-day error in human plasma was less than $2 \%$ (Table 2). In urine, mean percentage error was up to $9 \%$ (Table 3). Based on the inter- and intra-day $\mathrm{CV} \%$ and mean error, it could be determined that the lower limits of quantitation (LLQ) of metformin base were $7.8 \mathrm{ng} / \mathrm{mL}$ and $1.6 \mu \mathrm{g} / \mathrm{mL}$ based on $0.1 \mathrm{~mL}$ of human plasma and urine respectively (Tables 2 and 3 ).

In the test of assay applicability, plasma concentrations could be followed for up to $24 \mathrm{~h}$ following administration of the metformin dose. The observed Cmax were 2.47 and $2.37 \mathrm{mg} / \mathrm{L}$, occurring at corresponding tmax of 2.1 and $1.6 \mathrm{~h}$ respectively, for each of the two volunteers. The plasma elimination half-life was $3.7 \mathrm{~h}$ for both volunteers. The areas under the plasma concentration time curve from $0 \mathrm{~h}$ extrapolated to infinity $\left(\mathrm{AUC}_{0-\infty}\right)$ were 11.9 and $10.7 \mathrm{mg} \cdot \mathrm{h} / \mathrm{L}$. As expected, the measured concentrations of metformin in the $24 \mathrm{~h}$ cumulative urine samples were higher, being 149 and $168 \mu \mathrm{g} / \mathrm{mL}$ in the two volunteers. 


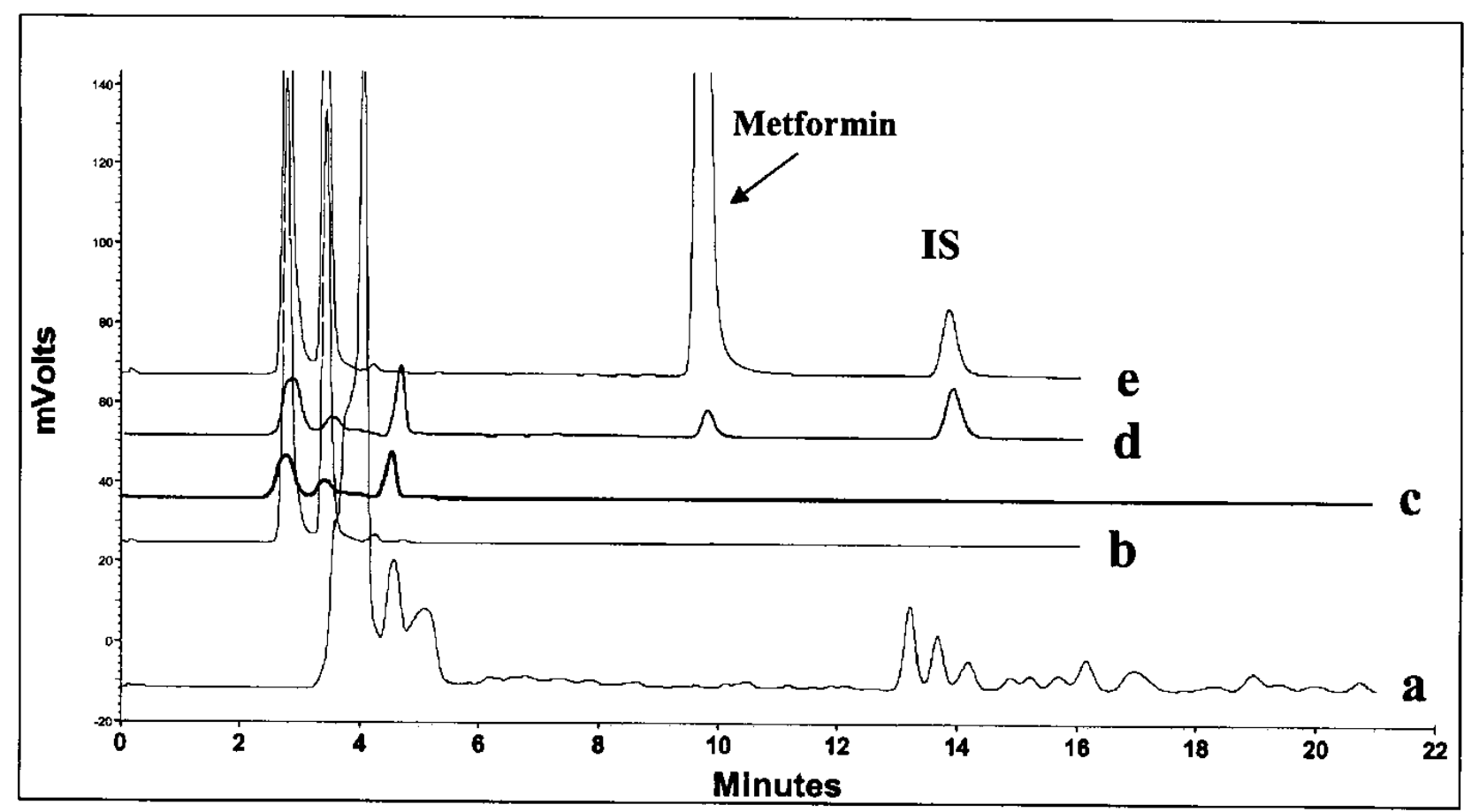

Figure 1. HPLC-UV chromatograms obtained for blank human plasma extracted by protein precipitation method (a), blank human urine (b), blank human plasma (c), human plasma sample after metformin administration (d) and human urine sample collected during 24 after metformin administration (e). In contrast to chromatogram a, chromatograms $b$ through e were extracted using the described liquid-liquid extraction technique.

Table 2. Validation data for the assay of metformin in human plasma, $n=5$

\begin{tabular}{|c|c|c|c|c|c|c|}
\hline \multirow{2}{*}{$\begin{array}{c}\text { Nominal } \\
\text { concentration of } \\
\text { HCl salt*, ng/mL }\end{array}$} & & Intraday & & \multicolumn{3}{|c|}{ Interday } \\
\hline & \multicolumn{3}{|c|}{$\operatorname{Mean} \pm S D$ ng/mL* $(C V \%)$} & \multirow{2}{*}{$\begin{array}{c}\text { Mean } \pm \text { SD, } \mathbf{n g} / \mathbf{m L} * \\
9.50 \pm 1.77\end{array}$} & \multicolumn{2}{|c|}{ CV\% Error \% } \\
\hline 10 & $\begin{array}{c}7.46 \pm 0.51 \\
(6.81)\end{array}$ & $\begin{array}{l}10.4 \pm 1.11 \\
(10.7)\end{array}$ & $\begin{array}{c}10.6 \pm 1.78 \\
(16.8)\end{array}$ & & 18.6 & -5.01 \\
\hline 30 & $\begin{array}{c}29.3 \pm 4.12 \\
(14.1)\end{array}$ & $\begin{array}{c}27.3 \pm 1.30 \\
\quad(4.76)\end{array}$ & $\begin{array}{c}31.2 \pm 0.62 \\
(1.98)\end{array}$ & $29.3 \pm 1.95$ & 6.64 & -2.37 \\
\hline 100 & $\begin{array}{c}97.2 \pm 5.06 \\
\quad(5.21)\end{array}$ & $\begin{array}{c}95.5 \pm 10.4 \\
\quad(10.9)\end{array}$ & $\begin{array}{c}97.9 \pm 1.86 \\
(1.90)\end{array}$ & $96.9 \pm 1.26$ & 1.31 & -3.14 \\
\hline 500 & $\begin{array}{c}492 \pm 3.44 \\
(0.70)\end{array}$ & $\begin{array}{c}493 \pm 6.67 \\
(1.35)\end{array}$ & $\begin{array}{c}522 \pm 34.4 \\
(6.58)\end{array}$ & $502 \pm 17.4$ & 3.46 & 0.46 \\
\hline 1000 & $\begin{array}{c}975 \pm 13.10 \\
(1.34)\end{array}$ & $\begin{array}{c}982 \pm 40.3 \\
(4.10)\end{array}$ & $\begin{array}{c}1096 \pm 39.7 \\
(3.63)\end{array}$ & $1017 \pm 67.8$ & 6.66 & 1.79 \\
\hline
\end{tabular}




\begin{tabular}{llll}
\hline \multicolumn{4}{l}{ Table 3. One day validation data for the assay of metformin in human urine, $\mathrm{n}=5$. } \\
\hline Nominal concentration of $\mathbf{H C l}$ salt* $\boldsymbol{\mu} \mathbf{g} / \mathbf{m L}$ & Mean $\pm \mathbf{S D}^{*}, \boldsymbol{\mu g} / \mathbf{m L}$ & $\mathbf{C V} \%$ & \%Error \\
\hline $\mathbf{2}$ & $2.09 \pm 0.04$ & 1.95 & 4.56 \\
$\mathbf{2 0}$ & $20.1 \pm 0.19$ & 0.93 & 0.34 \\
$\mathbf{1 0 0}$ & $105 \pm 2.09$ & 2.00 & 4.72 \\
$\mathbf{5 0 0}$ & $543 \pm 5.12$ & 0.94 & 8.66 \\
$\mathbf{2 0 0 0}$ & $2047 \pm 89.3$ & 4.36 & 2.34 \\
\hline
\end{tabular}

*To convert to base, multiply by 0.78 .

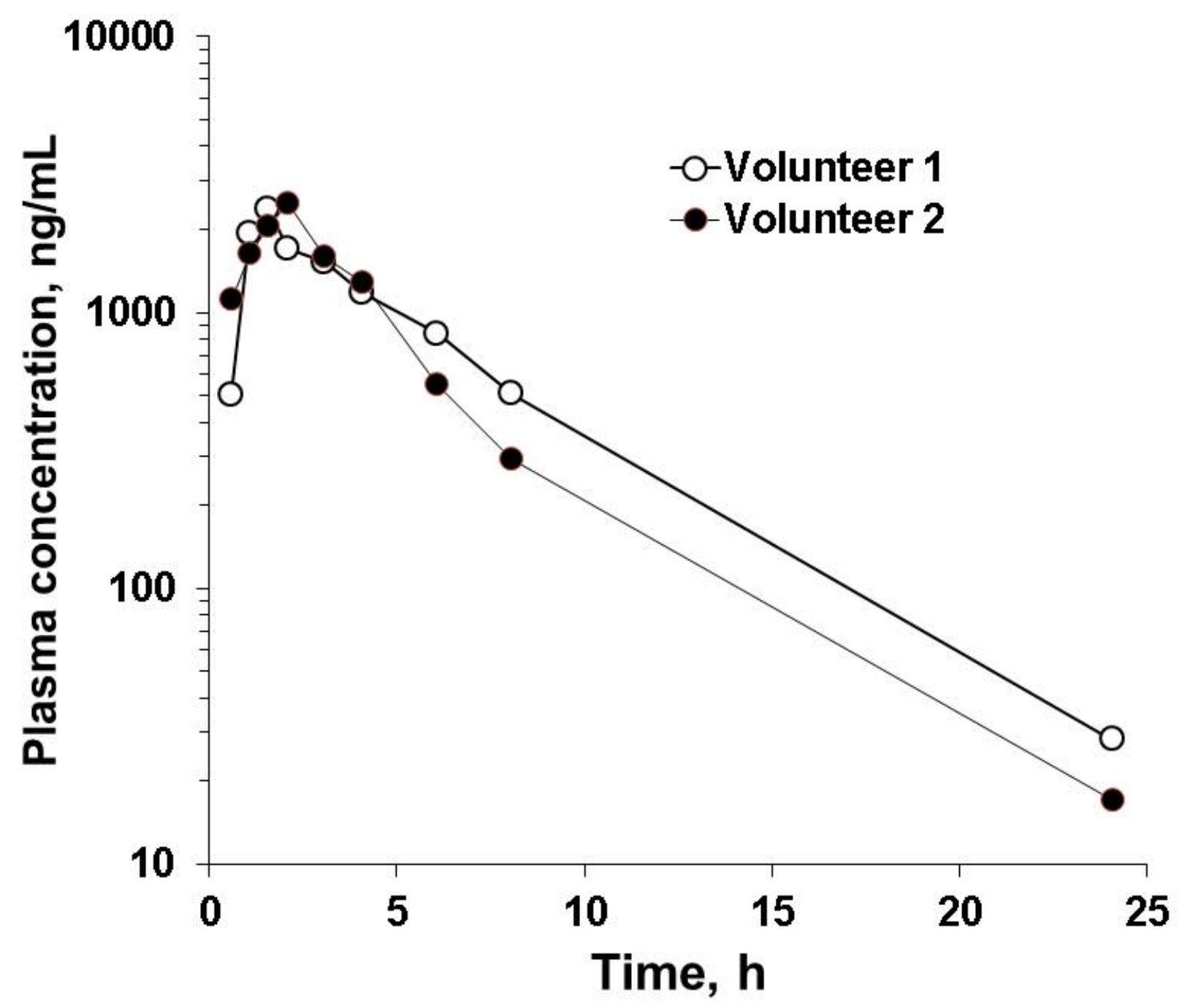


Figure 2. Plasma metformin concentration vs. time profiles after oral administration of $1000 \mathrm{mg}$ metformin $\mathrm{HCl}$ to two healthy individuals.

\section{DISCUSSION}

Several of the pre-existing methods cited for assay of metformin are presented in Table 1. To the best of our knowledge, there has been no HPLC method developed to determine metformin concentration in both human plasma and urine utilizing volume sizes as small as 0.1 $\mathrm{mL}$, using a liquid-liquid extraction procedure with a column specifically designed for reverse phase chromatography (e.g. C18 column).

The retention of metformin was examined on $\mathrm{C} 18, \mathrm{C} 8$ and phenyl columns with mobile phases that consisted of a mixture of phosphate solutions and acetonitrile. Metformin retention was very close to the column dead volume and no separation could be achieved from endogenous components using such columns and mobile phase composition. This is likely due to the polar nature of metformin inhibiting its ability to interact with the hydrophobic chains of C8, C18 and phenyl moiety. To overcome this problem, we tried manipulating the mobile phase composition by incorporating different concentrations of SDS. SDS was first used in metformin separation within tablet formulations by Kolte et al. (14) in a concentration of $5 \mathrm{mM}$. It is a well-known anionic surfactant used as a pseudo-stationary phase. At concentrations above the critical micelle concentration (CMC), SDS forms micelles which provide a pseudostationary phase that can effectively separate compounds based on partitioning between the aqueous mobile phase and the hydrophobic interior of the SDS micelles (10). Accordingly, it decreases the polarity of metformin, permitting its partitioning with the highly hydrophobic long C18 chain. As the amount of SDS was added, generally the longer would be the retention time of metformin on $\mathrm{C} 18$ column. A concentration of $3 \mathrm{mM}$ was found to be appropriate for the separation and both metformin and IS, and showed acceptable peak symmetry and suitable retention times (Fig. 1d,e).

Regarding extraction of metformin from biological matrices, protein precipitation followed by an organic solvent wash has used for plasma sample preparation for metformin (Table 1). As others have found, protein precipitation by itself was ineffective in removing all of the endogenous substances (Fig 1a). A disadvantage of protein precipitation is a lowering of sensitivity due to the sample dilution that it entails. Alkaline conditions have been used to extract metformin into a suitable organic solvent (3). For the present method workup, the extractability of metformin from plasma was tested in recovery experiments using dichloromethane, hexane, TBME and 1butanol $/ \mathrm{n}$-hexane (50:50 \% v/v) mixture. Both the TBME and 1-butanol/hexane mixtures were found to be most effective in terms of removing endogenous substances, but in terms of recovery, 1-butanol and hexane provided the optimal recovery. Both evaporation of extracting solvent and back-extraction into $0.2 \%$ acetic acid were tested. Back extraction of metformin into an acidic aqueous medium yielded a satisfactory outcome in terms of both selectivity and removal of interferences.

Use of the structurally related biguanide compound phenformin, which had been used as internal standard in other assays $(2,11)$, proved to be unsuitable for the chromatographic conditions employed, due to its delayed elution time. In those methods phenformin retention times were two to three-fold longer than that for metformin, thereby prolonging the total run time for the assay. In method workup, atenolol (7) and propranolol (17) were tried but were not suitable using the chromatographic conditions used. Ranitidine was used as reported by Amini et al. (3) and with our analytical conditions found it to offer high and reproducible recovery and reasonable retention time.

The assay was successfully used to monitor plasma concentrations of metformin for up to 24 $\mathrm{h}$ after dosing of $1000 \mathrm{mg}$ to two volunteers (Fig. 2). Each of the pharmacokinetic parameters measured in the subjects were in line with previous dose-normalized observations in volunteers (20).

\section{CONCLUSION}

The method displayed high calibers of sensitivity and selectivity for monitoring concentrations of metformin in both plasma and 
urine, based on a small $(0.1 \mathrm{~mL})$ sample volume. It was simple in terms of sample preparation and involved liquid-liquid extraction, which was rapid and accessible by the virtue of using a single $\mathrm{C} 18$ column. The method was also shown to be applicable for research involving both human plasma and urine specimens as part of a pharmacokinetic experiment.

\section{ACKNOWLEDGEMENT}

RQG is a recipient of a studentship from the Government of Egypt.

\section{REFERENCES}

1. Canadian Diabetes Association 2008 Clinical Practice Guidelines for the Prevention and Management of Diabetes in Canada. Can J Diab 2008; 32: S1-S201.

2. Aburuz S, Millership J, Mcelnay J. Determination of metformin in plasma using a new ion pair solid phase extraction technique and ion pair liquid chromatography. J Chromatogr B Analyt Technol Biomed Life Sci 2003; 798: 203209.

3. Amini H, Ahmadiani A, Gazerani P. Determination of metformin in human plasma by high-performance liquid chromatography. J Chromatogr B Analyt Technol Biomed Life Sci 2005; 824: 319-322.

4. Brohon J, Noel M. Determination of metformin in plasma therapeutic levels by gas--liquid chromatography using a nitrogen detector. J Chromatogr 1978; 146: 148-151.

5. Charles BG, Jacobsen NW, Ravenscroft PJ. Rapid liquid-chromatographic determination of metformin in plasma and urine. Clin Chem 1981; 27: 434-436.

6. Chen X, Gu Q, Qiu F, Zhong D. Rapid determination of metformin in human plasma by liquid chromatography-tandem mass spectrometry method. J Chromatogr B Analyt Technol Biomed Life Sci 2004; 802: 377-381.

7. Cheng CL, Chou CH. Determination of metformin in human plasma by highperformance liquid chromatography with spectrophotometric detection. J Chromatogr B Biomed Sci Appl 2001; 762: 51-58.

8. Garrett ER, Tsau J, Hinderling PH. Application of ion-pair methods to drug extraction from biological fluids. II. Quantitative determination of biguanides in biological fluids and comparison of protein binding estimates. J Pharm Sci 1972; 61: 1411-1418.

9. Heinig K, Bucheli F. Fast liquid chromatographic-tandem mass spectrometric (LC-MS-MS) determination of metformin in plasma samples. J Pharm Biomed Anal 2004; 34: 1005-1011.

10. Henry CW, 3rd, Shamsi SA, Warner IM. Separation of natural pyrethrum extracts using micellar electrokinetic chromatography. J Chromatogr A 1999; 863: 89-103.

11. Huupponen R, Ojala-Karlsson P, Rouru J, Koulu M. Determination of metformin in plasma by high-performance liquid chromatography. J Chromatogr 1992; 583: 270-273.

12. Kah Hay Y, Kok Khiang P. Simple highperformance liquid chromatographic method for the determination of metformin in human plasma. J Chromatogr B Biomed Sci Appl 1998; 710: 243-246.

13. Keal J, Somogyi A. Rapid and sensitive highperformance liquid chromatographic assay for metformin in plasma and urine using ion-pair extraction techniques. J Chromatogr 1986; 378: 503-508.

14. Kolte BL, Raut BB, Deo AA, Bagool MA, Shinde DB. Simultaneous determination of metformin in combination with rosiglitazone by reversed-phase liquid chromatography. J Chromatogr Sci 2004; 42: 70-73.

15. Matin SB, Karam JH, Forshan PH. Simple elcetron capture gas chromatographic method for the determination of oral hypoglycemic biguanidis in biological fluids. Anal Chem 1975; 47: 545-548.

16. Pentikainen PJ, Neuvonen PJ, Penttila A. Pharmacokinetics of metformin after intravenous and oral administration to man. Eur $\mathrm{J}$ Clin Pharmacol 1979; 16: 195-202.

17. Porta V, Schramm SG, Kano EK, Koono EE, Armando YP, Fukuda K, Serra CH. HPLC-UV determination of metformin in human plasma for application in pharmacokinetics and bioequivalence studies. J Pharm Biomed Anal 2008; 46: 143-147.

18. Sambol NC, Chiang J, Lin ET, Goodman AM, Liu CY, Benet LZ, Cogan MG. Kidney function and age are both predictors of pharmacokinetics of metformin. J Clin Pharmacol 1995; 35: 10941102.

19. Scheen AJ. Clinical pharmacokinetics of metformin. Clin Pharmacokinet 1996; 30: 359371.

20. Somogyi A, Stockley C, Keal J, Rolan P, Bochner F. Reduction of metformin renal tubular 
secretion by cimetidine in man. $\mathrm{Br} \mathrm{J}$ Clin Pharmacol 1987; 23: 545-551.

21. Song JZ, Chen HF, Tian SJ, Sun ZP. Determination of metformin in plasma by capillary electrophoresis using field-amplified sample stacking technique. J Chromatogr B Biomed Sci Appl 1998; 708: 277-283.

22. Tache F, David V, Farca A, Medvedovici A. HPLC-DAD determination of Metformin in human plasma using derivatization with $\mathrm{p}$ nitrobenzoyl chloride in a biphasic system. . Microchemical Journal 2001; 68: 13-19.

23. Tahara K, Yonemoto A, Yoshiyama Y, Nakamura T, Aizawa M, Fujita Y, Nishikawa T. Determination of antihyperglycemic biguanides in serum and urine using an ion-pair solid-phase extraction technique followed by HPLC-UV on a pentafluorophenylpropyl column and on an octadecyl column. Biomed Chromatogr 2006; 20: 1200-1205.

24. Vesterqvist O, Nabbie F, Swanson B. Determination of metformin in plasma by high- performance liquid chromatography after ultrafiltration. J Chromatogr B Biomed Sci Appl 1998; 716: 299-304.

25. Wang Y, Tang Y, Gu J, Fawcett JP, Bai X. Rapid and sensitive liquid chromatographytandem mass spectrometric method for the quantitation of metformin in human plasma. J Chromatogr B Analyt Technol Biomed Life Sci 2004; 808: 215-219.

26. Zarghi A, Foroutan SM, Shafaati A, Khoddam A. Rapid determination of metformin in human plasma using ion-pair HPLC. J Pharm Biomed Anal 2003; 31: 197-200.

27. Zhang M, Moore GA, Lever M, Gardiner SJ, Kirkpatrick CM, Begg EJ. Rapid and simple high-performance liquid chromatographic assay for the determination of metformin in human plasma and breast milk. J Chromatogr B Analyt Technol Biomed Life Sci 2002; 766: 175-179. 